\title{
Regulation by Nicotine of Gpr5I and Ntrk2 Expression in Various Rat Brain Regions
}

\author{
Dongxiao Sun ${ }^{1,2}$, Weihua Huang', Yoon Y Hwang', Yuan Zhang', Qin Zhang ${ }^{2}$ and Ming D Li*,I \\ 'Section of Neurobiology, Department of Psychiatric Medicine, University of Virginia, Charlottesville, VA, USA; ${ }^{2}$ Department of Animal Genetics \\ and Breeding, China Agricultural University, Beijing, PR China
}

\begin{abstract}
Our previous genetic studies demonstrated that variants of the $\gamma$-Aminobutyric acid B receptor subunit 2 (GPR5I) and neurotrophic tyrosine kinase receptor type 2 (NTRK2) genes are significantly associated with nicotine dependence (ND) in smokers. However, whether such genetic associations lead to changes in the expression of the two genes in response to nicotine remains undetermined. In this study, we investigated the regulatory effect of nicotine on the expression of Gpr5I and Ntrk2 in seven rat brain regions during the administration of nicotine in a daily dose of $3.15 \mathrm{mg} / \mathrm{kg}$ for 7 days. With quantitative real-time RT-PCR, we found that nicotine increased the mRNA of Gpr5 I by 70, 78, and 32\% in the amygdala, striatum, and prefrontal cortex (PFC), respectively, but decreased by $54 \%$ in the nucleus accumbens (NA). The Gpr5I protein was upregulated by nicotine in the amygdala (26\%), striatum (73\%), PFC (28\%), and medial basal hypothalamus $(\mathrm{MBH} ; 19 \%)$ but downregulated in the NA (-72\%). Similarly, the mRNA level of Ntrk2 was enhanced by nicotine in the striatum (86\%) and PFC (38\%), but decreased in the NA (-46\%) and ventral tegmental area (VTA; -49\%). A significant change in protein expression was also obtained for Ntrk2 in the PFC (24\%), MBH (33\%), NA (-33\%), and VTA (-70\%). Interestingly, these two genes showed a closely coordinated expression pattern in response to nicotine in most of the brain regions examined. In summary, our results demonstrate that the expression of Gpr5I and Ntrk2 is significantly regulated by nicotine at both the mRNA and protein levels in various brain regions, which provides further evidence that these two genes are involved in the etiology of ND, as reported in our previous genetic association studies in humans.
\end{abstract}

Neuropsychopharmacology (2007) 32, I I0- | |6. doi: I0.1038/sj.npp. I 30 I I34; published online 21 June 2006

Keywords: nicotine; rat brain; Gpr51; Ntrk2; expression

\section{INTRODUCTION}

Nicotine dependence (ND) is a complex quantitative trait that is influenced by both genetic and environmental factors (for recent reviews, see Sullivan and Kendler, 1999; Li et al, 2003a). Meta-analysis of 17 twin studies determined that the weighted mean heritability of liability for ND is 0.56 for all smokers (Li et al, 2003a). The habit-forming actions of nicotine appear to be triggered through the stimulation of dopamine secretion in the ventral tegmental area (VTA), which projects to the nucleus accumbens (NA), in a manner similar to other drugs of abuse such as cocaine, amphetamine, or morphine (Pontieri et al, 1996; Rose and Corrigall, 1997).

\footnotetext{
* Correspondence: Dr MD Li, Section of Neurobiology, Department of Psychiatric Medicine, University of Virginia, 1670 Discovery Drive, Suite 101, Charlottesville, VA 229II, USA, Tel: + I 4342430566 , Fax: + I 434973 7031, E-mail: ml2km@virginia.edu

Received II December 2005; revised 2 May 2006; accepted 16 May 2006

Online publication: 23 May 2006 at http://www.acnp.org/citations/ Npp052306050730/default.pdf
}

Previously, we reported that several chromosomal regions are likely to harbor susceptibility gene(s) for ND in the 313 extended Framingham Heart Study (FHS) families (Li et al, 2003b; Wang et al, 2005). Of these regions, that on chromosome 9q22-23 appears to be interesting because three additional studies reported a possible linkage, at a nominally significant level, with smoking behaviors (Bergen et al, 1999; Bierut et al, 2004; Gelernter et al, 2004). The genes for both $\gamma$-Aminobutyric acid $(\mathrm{GABA})_{\mathrm{B}}$ receptor subunit 2 (GPR51) and neurotrophic tyrosine kinase receptor type 2 (NTRK2) have been mapped within this linkage region (Nakagawara et al, 1995; Valent et al, 1997; Martin et al, 1999) and suggested to play a significant role in drug addiction. To determine if these two genes are involved in the etiology of ND, we conducted family-based association studies using an independent cohort recruited by us during 1999-2004 and found that these two genes indeed are significantly associated with ND (Beuten et al, 2005a; Beuten et al, 2006). With the same cohort, we also found a significant association of brain-derived neurotrophic factor $(B D N F)$, which exerts its regulatory effects through the activation of NTRK2, with ND in EuropeanAmerican male smokers (Beuten et al, 2005b). 
GABA is a major inhibitory neurotransmitter in the mammalian central nervous system and plays a key role in modulating neuronal activity via the ionotropic $\mathrm{GABA}_{\mathrm{A}}$ and metabotropic $\mathrm{GABA}_{\mathrm{B}}$ receptors (for a review, see Bettler et al, 2004). GABA neurons are part of the mesolimbic DA system, and GABAergic transmission regulates reinforcement by several drugs of abuse through an inhibitory action on mesolimbic dopaminergic neurons via $\mathrm{GABA}_{\mathrm{B}}$ receptors (Bardo, 1998; Gong et al, 1998; Cousins et al, 2002). Preclinical and clinical studies indicate that $\mathrm{GABA}_{\mathrm{B}}$ receptor agonists, that is, baclofen, reduce addictive behaviors associated with nicotine, cocaine, and morphine use in rats (Cousins et al, 2002; Fadda et al, 2003). On the other hand, expression of BDNF, a member of the neurotrophin family, has been found to be coregulated with that of NTRK 2 by ethanol at both the mRNA and protein levels, and by brain injury at the mRNA level (Hicks et al, 1999; Zhang et al, 2000; Ge et al, 2004; Zaidi et al, 2005). Several studies have demonstrated that BDNF is involved in the survival and differentiation of DA neurons and regulates the reward pathways associated with the actions of drug abuse (Hyman et al, 1991; Spina et al, 1992; Horger et al, 1999; Kenny et al, 2000; Meredith et al, 2002). Cocaine, methamphetamine, morphine, alcohol, and nicotine can increase Bdnf expression in the rat cortical area, hippocampus, and hypothalamus (Tapia-Arancibia et al, 2001; Le Foll et al, 2005). Microinjection of either Bdnf or Ntrk2 antibodies decreases the elevation of DA stimulated by methamphetamine and cocaine and induces DA-related behaviors in rat NA (Horger et al, 1999; Narita et al, 2003). Further, BDNF modulates GABAergic transmission in the visual cortex of rats and mice (Huang et al, 1999; Mizoguchi et al, 2003b) and accelerates the responsiveness to GABA in cultured granule cells (Kubo et al, 1995; Lin et al, 1998; Rieff et al, 1999; Borghesani et al, 2002; Mizoguchi et al, 2003b).

As for regulation of Gpr51 and Ntrk2 by nicotine, however, only a few studies have been reported (French et al, 1999; Kenny et al, 2000; Amantea et al, 2004; Li et al, 2004). Therefore, the primary purpose of this study was to determine whether nicotine has regulatory effects on the expression of Gpr51 and Ntrk2 in the rat brain.

\section{MATERIALS AND METHODS}

\section{Animals, Nicotine Administration, and Brain Punches}

Adult male Holtzman rats (250-350 g; HSD, Madison, WI) were randomly divided into nicotine-treated and control groups. For the former, nicotine bitartrate was administered through osmotic minipumps (Model 2ML1; Azlet Corp., Palo Alto, CA) in a daily dose of $3.15 \mathrm{mg} / \mathrm{kg}$ (calculated as the base) in saline ( $\mathrm{pH} 7.4$ ) for 7 days, as originally reported by Malin et al, 1992 and replicated by several other laboratories (Hildebrand et al, 1997; Epping-Jordan et al, 1998; Watkins et al, 2000). This model produces a stable plasma nicotine concentration of ca. $44 \mathrm{ng} / \mathrm{ml}$, which is very similar to that in smokers consuming 30 cigarettes daily (Murrin et al, 1987; Benowitz, 1988). Rats in the control group were handled and treated exactly the same, except that only saline was delivered by the minipumps. All rats were housed at $22^{\circ} \mathrm{C}$ on a $12 \mathrm{~h}$ light/dark cycle. Standard laboratory rat chow and water were freely available. To ensure we had enough sample size for real-time RT-PCR or Western blotting assays, seven animals were included for each experimental group. Brain punches used for real-time RT-PCR and Western blotting assays were from two independent animal experiments under an identical treatment regimen.

After 7 days of nicotine treatment, rats were anesthetized with isoflurane, and the brains were removed immediately for sectioning. Coronal 2-mm sections were prepared using a Stoelting tissue slicer (Chicago, IL). Punches from the selected brain regions were excised using a tissue set from myNeuroLab.com (St Louis, MO) based on coordinates from Paxinos and Watson (1986). For the NA, each sample contained the core and shell of the accumbens dissected using bilateral $2.0-\mathrm{mm}$-diameter punches. For the amygdala region, each sample contained bilateral 2.0-mm-diameter dissections centered in the basolateral nuclear complex. For the VTA, each sample contained a single 1.5-mm-diameter punch that was centered in the dense field of dopaminecontaining cells. All animal-related experimental procedures were approved by the Institutional Animal Use and Care Committee.

\section{RNA Isolation, Reverse Transcription, and Real-Time Polymerase Chain Reaction (Quantitative RT-PCR)}

Total RNA was extracted with TRIzol reagent (Invitrogen, Carlsbad, CA). One microgram of total RNA was reverse transcribed in a final volume of $20 \mu \mathrm{l}$ containing $4 \mu \mathrm{l}$ of $5 \times$ first-strand buffer (250 mM Tris- $\mathrm{HCl}, \mathrm{pH} 8.3 ; 375 \mathrm{mM} \mathrm{KCl}$; $15 \mathrm{mM} \mathrm{MgCl}_{2}$ ), $10 \mathrm{mM}$ DTT, $0.5 \mathrm{mM}$ each dNTP, $40 \mathrm{U}$ $\mathrm{RNaseOUT}^{\mathrm{TM}}, 1 \mu \mathrm{l}$ of $50 \mathrm{nM}$ random hexamers, and $200 \mathrm{U}$ of Superscript II RNase $\mathrm{H}^{-}$reverse transcriptase (Invitrogen).

The TaqMan ${ }^{\circledR}$ probes and primers were designed according to the cDNA sequences of rat Gpr51 (GenBank Accession No. NM031802) and Ntrk2 (GenBank Accession No. NM012731) and synthesized by Applied Biosystems (Foster, CA). The forward and reverse primer sequences were $5^{\prime}$-TTCAACATCAAGAACCGG- $3^{\prime}$ and $5^{\prime}$-CAGAAAA GGTTAGAAATC-3', respectively, for Gpr51, and $5^{\prime}$-AGATC TCGCTTCCACTGTATAGCAT- $3^{\prime}$ and $5^{\prime}$-GGCTTGACATCT TAATCAGCTTTTG-3' for Ntrk2, with an expected PCR product size of $123 \mathrm{bp}$ for Gpr51 and $81 \mathrm{bp}$ for Ntrk2. The TaqMan probes used for Gpr51 and Ntrk2 were $5^{\prime}$ TTCAACATCAAGAACCGG- $3^{\prime}$ and 5'-CAGAAAAGGTTA GAAATC-3', respectively. Amplification of $2 \mu \mathrm{l}$ of cDNA was carried out in a total volume of $20 \mu \mathrm{l}$ according to the manual of TaqMan ${ }^{\circledR}$ Gene Expression Assays (Applied Biosystems). The mRNA level of each gene was determined using a calibration method (Winer et al, 1999) and normalized to that of $18 \mathrm{~S}$ rRNA in each sample.

\section{Western Blotting Analysis}

Total protein was extracted from individual frozen brain punches of an independent animal experiment by homogenization with a sonicator in RIPA buffer $(50 \mathrm{mM}$ Tris$\mathrm{HCl}, \mathrm{pH} \quad 8.0 ; 150 \mathrm{mM} \mathrm{NaCl}, 1 \% \mathrm{NP}-40,0.5 \%$ sodium deoxycholate, and $0.1 \%$ SDS), and the protein concentration was determined by the Bio-Rad Protein Assay (Bio-Rad Laboratories, Hercules, CA). Thirty micrograms of total protein was separated by $8 \%$ SDS-PAGE followed by 
transfer to nitrocellulose membranes $(0.45 \mu \mathrm{m})$ at $80 \mathrm{~V}$ for $1.5 \mathrm{~h}$. The membrane was first incubated in a blocking buffer (6\% nonfat milk and $0.2 \%$ Tween 20 ) for $0.5 \mathrm{~h}$ at room temperature and then overnight at $4{ }^{\circ} \mathrm{C}$ in the blocking buffer containing rabbit anti-Gpr51 antibody (dilution 1:200; Chemicon, Temecula, CA) or mouse anti-Ntrk2 antibody (dilution 1:1000; BD Biosciences, San Jose, CA). After three washes in TBST (10 mM Tris- $\mathrm{HCl}, \mathrm{pH} 8.0 ; 0.15 \mathrm{M}$ $\mathrm{NaCl} ; 0.2 \%$ Tween 20 ) for $10 \mathrm{~min}$ each, the membranes were exposed to horseradish peroxidase-conjugated secondary antibodies at $4{ }^{\circ} \mathrm{C}$ for $3 \mathrm{~h}$, and then exposed to $\mathrm{X}$-ray film. After hybridization with the antibody of interest, membranes were stripped and re-probed with antibody to $\beta$-actin (dilution 1:10000; Santa Cruz Biotechnology, Santa Cruz, CA), which was used for normalization of the protein content of each sample. Then, the films were scanned for quantitative analysis with ImageQuant 5.2 (Molecular Dynamics, Sunnyvale, CA).

\section{Statistical Analysis}

The significance of differences between the nicotine-treated and control groups was analyzed by Student's $t$-test, and a $P$-value of $\leqslant 0.05$ was considered statistically significant.

\section{RESULTS}

\section{Changes in Expression of Gpr51 mRNA}

To identify the regulatory effects of chronic nicotine treatment on Gpr51 mRNA in rat brain, quantitative RTPCR analysis was employed. After normalization with the corresponding $18 \mathrm{~S}$ rRNA mRNA level of each sample followed by Student's $t$-test, we found that the mRNA level of Gpr51 was significantly upregulated, by $70 \%(P<0.01)$, $78 \%(P<0.01)$, and $32 \%(P<0.01)$, in the amygdala, striatum, and prefrontal cortex (PFC), respectively, of the nicotine-treated rats compared with saline-treated controls. On the other hand, we found significant downregulation of Gpr51 mRNA, by $54 \%(P<0.01)$, in the NA of nicotinetreated rats relative to controls (Figure 1).

\section{Protein Expression Changes of Gpr51}

To determine if the protein level is also changed by nicotine, we performed Western blotting analysis of the seven brain regions. To check the loading efficiency and protein concentration, we conducted Western blotting analysis for $\beta$-actin on the same samples. The Western blotting images for Gpr51 and $\beta$-actin in the seven brain regions are shown in Figure 2 . The protein level was significantly upregulated, by $26 \%(P<0.05), 73 \%(P<0.01)$, and $28 \%(P<0.01)$, in the amygdala, striatum, and PFC, respectively, and downregulated by $72 \%(P<0.05)$ in the NA. By comparing the expression trends of Gpr51 in response to nicotine, we found a closely parallel pattern between the mRNA and protein levels in six of the seven brain regions. The only difference was in the $\mathrm{MBH}$, in which no significant difference was obtained in mRNA, zbut a significant difference was achieved in the protein $(18 \%, P<0.05)$.

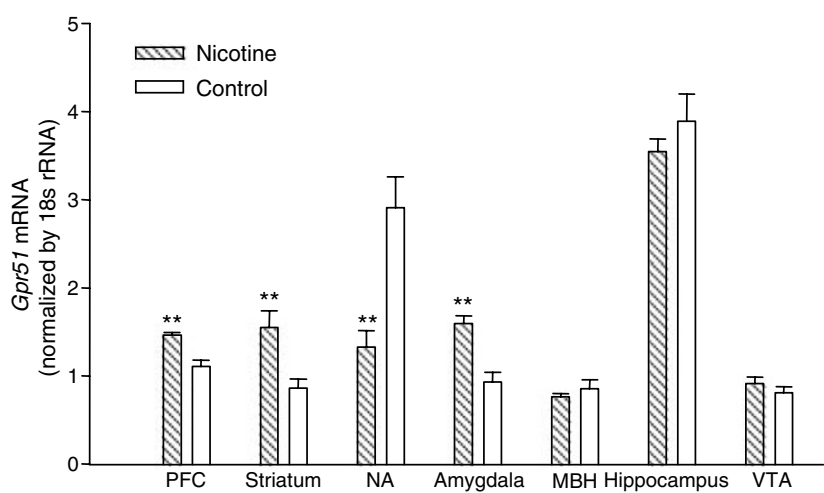

Figure I Comparison of mRNA levels of Gpr5I between nicotinetreated and control groups in seven rat brain regions after 7 days of nicotine administration, which showed that the mRNA level of Gpr5I was increased by nicotine by 70,78 , and $32 \%$ in the amygdala, striatum, and PFC, respectively, and decreased by $54.1 \%$ in the NA. Values are the mean \pm SEM of six animals per group. ${ }^{*} P<0.05$, ${ }^{*} * P<0.0$ l.

\section{Expression Changes of Ntrk2 mRNA}

Figure 3 shows a summary of mRNA level of Ntrk2 in the rat brain regions, which indicated that the gene was significantly altered at the mRNA level in four of the seven regions. Together, we found that mRNA level of Ntrk2 was significantly increased, by $86 \%(P<0.05)$ and $38 \%$ $(P<0.05)$, in the striatum and $\mathrm{PFC}$, respectively, but decreased by $46 \%(P<0.05)$ and $49 \%(P<0.05)$ in the NA and VTA, respectively, in the nicotine-treated group compared with the control animals.

\section{Protein Expression Changes of Ntrk2}

With Western blotting analysis, we found that nicotine significantly increased the level of Ntrk2 protein, by $24 \%$ $(P<0.01)$, in the PFC and decreased it by $33 \%(P<0.05)$ and $70 \%(P<0.05)$ in the NA and VTA, respectively (Figure 4$)$, which is consistent with the change in the amount of mRNA. In addition, we observed a significant increase, $30 \%$ $(P<0.05)$, in Ntrk2 protein in the $\mathrm{MBH}$ and no significant increase in the striatum, which is different from what we observed for Ntrk2 mRNA in the two regions.

\section{DISCUSSION}

Previously, we reported identification of an approximately $13-\mathrm{cM}$ genomic region on chromosome 9q22-q23 that showed a suggestive linkage to smoking quantity in the FHS samples (Li et al, 2003b). This linkage to ND at a nominally significant level was supported by three independent linkage studies for smoking behavior (Bergen et al, 1999; Bierut et al, 2004; Gelernter et al, 2004). Furthermore, this genomic region has been linked to alcohol consumption in the FHS cohort (Ma et al, 2003). Within this region, GPR51 and NTRK2 represent two plausible candidate genes for ND based on their biological functions and locations (Nakagawara et al, 1995; Valent et al, 1997; Martin et al, 2001). Recently, we conducted a family-based association analysis of GPR51 and NTRK2 with ND in an independent cohort, namely the mid-South Tobacco families, that we recruited 

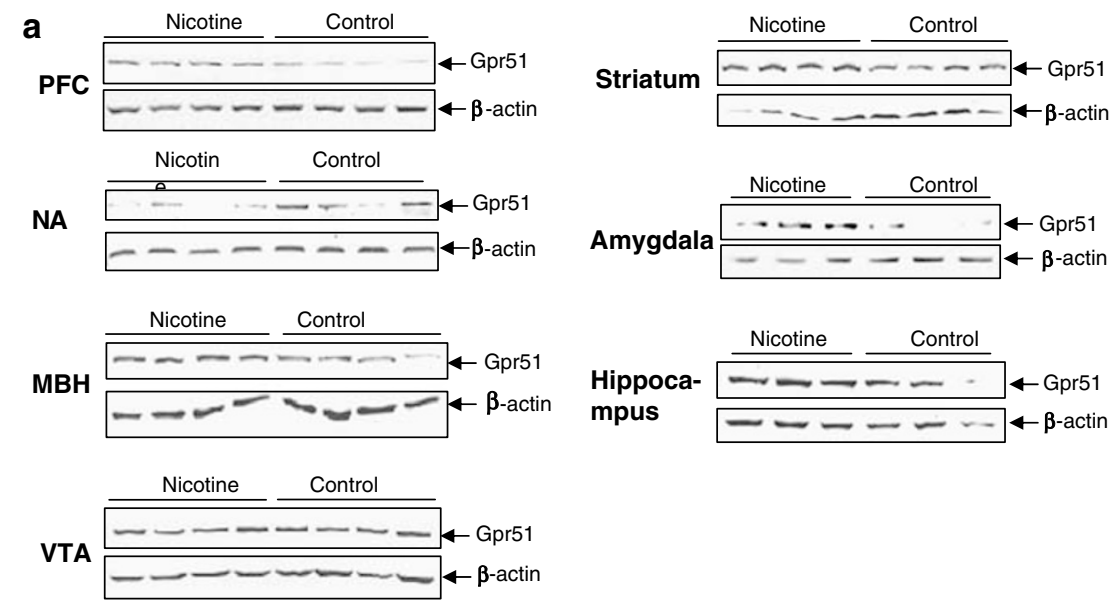

b

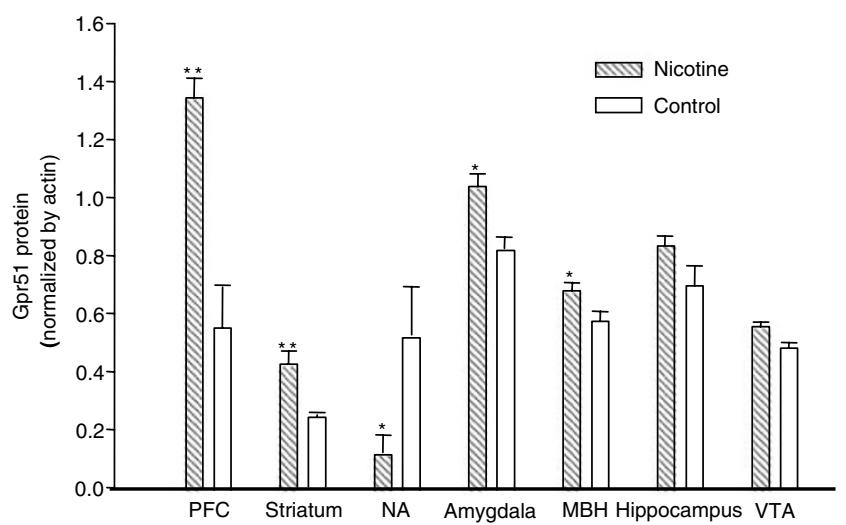

Figure 2 Western blotting analysis of Gpr5I expression in seven rat brain regions. (a) shows the results for Gpr5I and $\beta$-actin in seven brain regions. (b) summarizes the statistical analysis of the Gpr5I protein level normalized by the corresponding $\beta$-actin level, which indicated that nicotine increased Gpr5 I protein level by $26,28,73$, and $19 \%$ in the amygdala, striatum, $\mathrm{PFC}$, and $\mathrm{MBH}$, respectively, and reduced its expression by $72 \%$ in the $\mathrm{NA}$. Values are the mean \pm SEM of $3-5$ animals per group. $* P<0.05$, $* * P<0.01$.

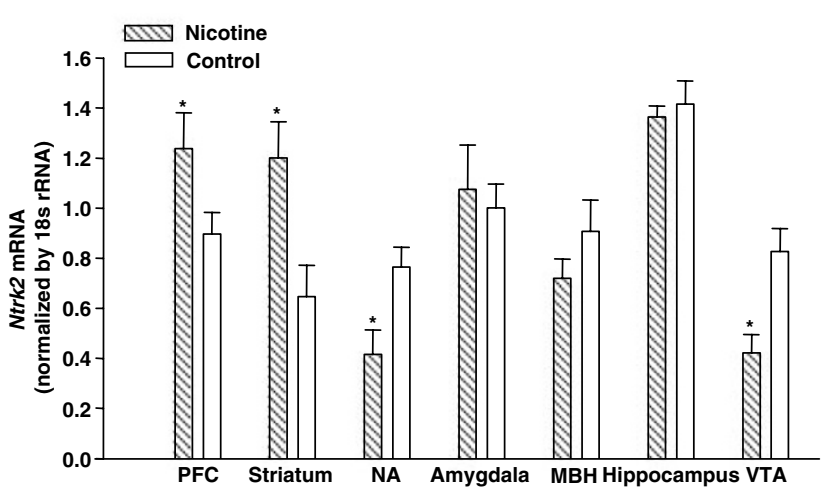

Figure 3 Comparison of mRNA levels of Ntrk2 between nicotinetreated and control groups in seven rat brain regions after seven days of nicotine administration, which showed that the mRNA level of Ntrk2 was enhanced by nicotine in the striatum (86\%) and PFC (38\%) but decreased in the NA $(-46 \%)$ and VTA $(-49 \%)$. Values are the mean \pm SEM of 6 animals per group. ${ }^{*} P<0.05$.

during 1999-2004, which revealed that these two genes are significantly associated with ND (Beuten et al, 2005a; Beuten et al, 2006). In the present study, we demonstrated that chronic nicotine treatment significantly modulated Gpr51 expression in the amygdala, PFC, striatum, NA, and
$\mathrm{MBH}$, and Ntrk2 expression in the $\mathrm{PFC}, \mathrm{NA}, \mathrm{MBH}$, and VTA. Furthermore, the mRNA patterns of the two genes in response to nicotine were consistent with the protein levels in most of these brain regions. The only difference noticed between mRNA and protein for Gpr51 was in the MBH (no change in mRNA $v s$ a $19 \%$ increase in protein) and that for Ntrk2 in the MBH (no change in mRNA vs 33\% increase in protein) and striatum ( $86 \%$ increase in mRNA $v s$ no change in protein). This may be attributable to the regulation by nicotine at the translation level in these regions or to protein degradation after translation.

In recent years, growing experimental evidence has supported the hypothesis that activation of GABAergic transmission and $B D N F / N T R K 2$ is closely connected with the mesolimbic dopaminergic pathway during rewarding processes for drug abuse (Bowery et al, 1987; Horger et al, 1999; Tapia-Arancibia et al, 2001; Cousins et al, 2002; Fadda et al, 2003; Narita et al, 2003; Tapia-Arancibia et al, 2004; Le Foll et al, 2005; Paterson et al, 2005). However, to date, there have been only a few studies reported on the regulation of Gpr51 and Ntrk2 expression by nicotine. For example, Amantea et al (2004) reported that G-protein coupling to $\mathrm{GABA}_{\mathrm{B}}$ receptors is significantly reduced in the $\mathrm{PFC}$ and NA of nicotine-treated rats, whereas $\mathrm{GABA}_{\mathrm{B}}$ receptor density and affinity are not altered. Another study found that 

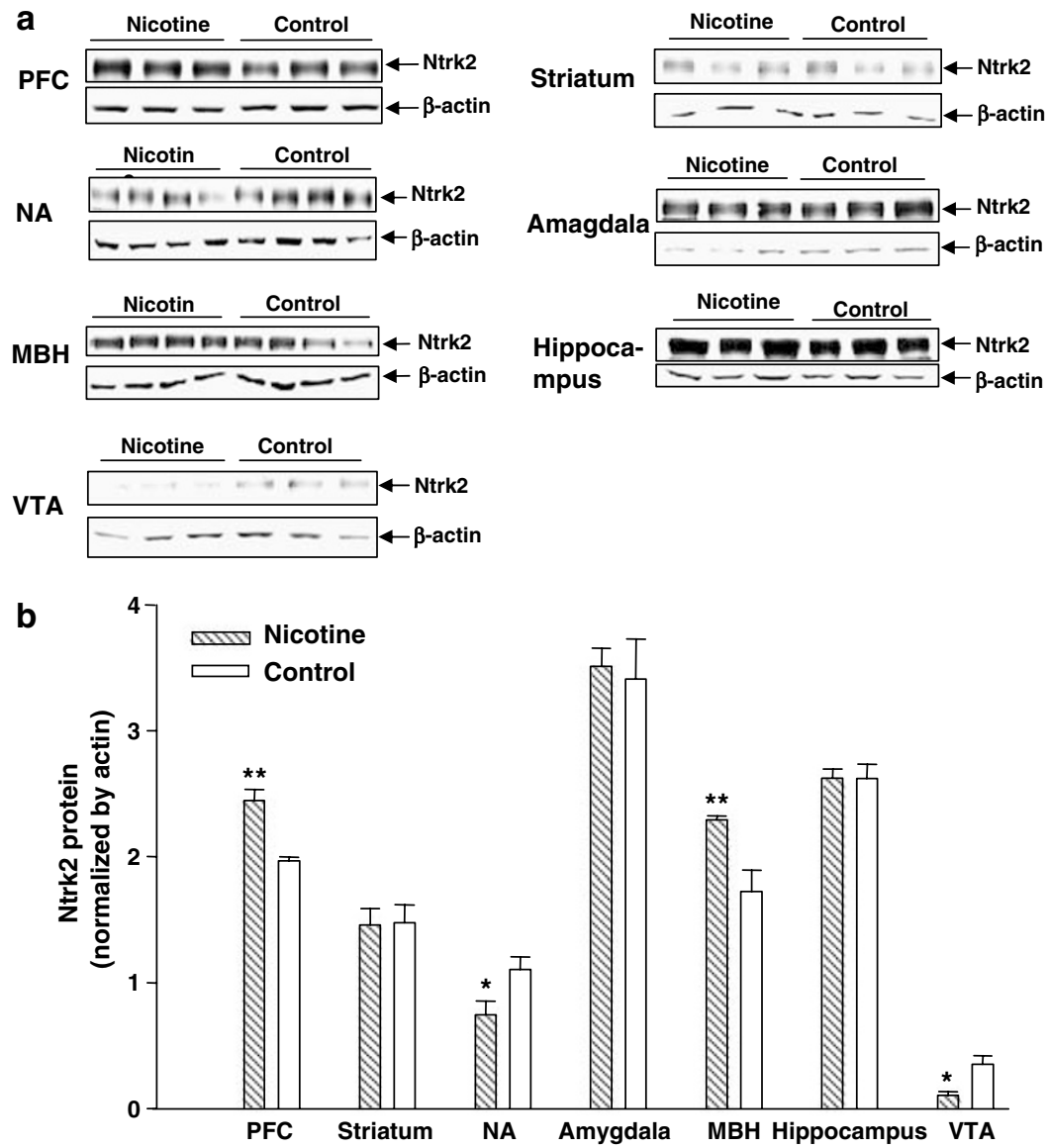

Figure 4 Western blotting analysis for Ntrk2 expression in seven rat brain regions. (a) shows the results for Ntrk2 and $\beta$-actin in seven brain regions. (b) summarizes the statistical analysis of the Ntrk2 protein level normalized by the corresponding $\beta$-actin level, which indicated that nicotine enhanced Ntrk2 protein by 24 and $33 \%$ in the PFC and $\mathrm{MBH}$, respectively, and reduced its expression by 33 and $70 \%$ in the NA and VTA, respectively. Values are the mean \pm SEM of $3-5$ animals per group. $* P<0.05$, $* * P<0.01$.

nicotine slightly decreased Gpr51 mRNA in the rat PFC (Li et $a l, 2004)$, whereas we found herein that nicotine increased Gpr51 expression in the PFC but decreased it in the NA. Such discrepancies in the PFC may result from different nicotine doses or treatment times or heterogeneity of the PFC region. In the present study, for example, nicotine was administered by osmotic minipump infusion in a daily dose of $3.15 \mathrm{mg} / \mathrm{kg}$ in saline for 7 days, whereas in the other two studies, nicotine was administered by subcutaneous injection $(0.4 \mathrm{mg} / \mathrm{kg}$ for 14 days) (Amantea et al, 2004) or orally ( $3 \mathrm{mg} /$ day for 4 weeks) (Li et al, 2004). Different doses of nicotine might lead to different degrees of activation of nAChRs on the GABA and DA neurons, which may impact the expression of GABA receptor and GABA release in these brain areas. Further, various treatment times could cause different extents of desensitization of nAChRs, which may subsequently produce different effects on the expression of Gpr51.

On the other hand, our finding that Ntrk2 mRNA was enhanced by nicotine treatment in the striatum is consistent with the results reported by Maggio et al (1998), in which chronic nicotine treatment increased the expression of $B d n f$ in rat striatum. Conversely, another report showed that chronic nicotine administration, in a dose of $0.4 \mathrm{mg} / \mathrm{kg}$ through injection twice daily for 7 days, inhibited the expression of $B d n f$ mRNA and protein in rat striatum (Yeom et al, 2005). Also, we found no alteration of Ntrk2 expression in the hippocampus, which is contradictory to the report that chronic nicotine treatment by injection $(0.5 \mathrm{mg} / \mathrm{kg})$ twice daily for 7 days increased, and acute nicotine treatment decreased, the $B d n f$ mRNA level in rat hippocampus (French et al, 1999; Kenny et al, 2000). Such differences among studies are likely secondary to the different doses and times of nicotine treatment. Coincident with Gpr51 in the present study, the expression of Ntrk2 showed a region-specific pattern. On the basis of the function of BDNF/NTRK2 pathway in the mesolimbic dopaminergic process, both interaction between BDNF and DA and network among various brain regions could lead to the different expression levels of Ntrk2 in different regions.

In addition, we found that the expression pattern of Gpr51 almost coincided with that of Ntrk2. Similarly, previous studies indicated the interactions between BDNF and GABAergic processes in cultured granule cells and rat or mouse visual cortex (Kubo et al, 1995; Lin et al, 1998; Huang et al, 1999; Rieff et al, 1999; Borghesani et al, 2002; Mizoguchi et al, 2003a), Further, both Bdnf/Ntrk2 and Gpr51 are involved in protein kinase C (PKC)-related intracellular signal transduction (Kaplan and Stephens, 
1994; Zirrgiebel et al, 1995; Huang and Reichardt, 2001; Kubota et al, 2003). These findings imply that a common pathway coregulates the expression of Gpr51 and Bdnfl Ntrk2 and leads to some interactions between them during the dopaminergic process. The variation between the expression pattern of Gpr51 and Ntrk2 in the amygdala, striatum, and VTA may mean that the expression of Gpr51 in the VTA and Ntrk2 in the amygdala and striatum is not sufficient to be detectable by the techniques used in the present study.

In summary, our results demonstrated that chronic nicotine administration modulated the expression of Gpr51 and Ntrk2 in various rat brain regions, providing further support for our earlier observations that both GPR51 and NTRK2 are important players in the etiology of ND in human smokers. Therefore, these two genes represent critical candidates for future investigation on ND.

\section{ACKNOWLEDGEMENTS}

This project was funded by NIH Grants DA-12844 and DA-13783 to MDL.

\section{REFERENCES}

Amantea D, Tessari M, Bowery NG (2004). Reduced G-protein coupling to the GABAB receptor in the nucleus accumbens and the medial prefrontal cortex of the rat after chronic treatment with nicotine. Neurosci Lett 355: 161-164.

Bardo MT (1998). Neuropharmacological mechanisms of drug reward: beyond dopamine in the nucleus accumbens. Crit Rev Neurobiol 12: 37-67.

Benowitz NL (1988). Drug therapy. Pharmacologic aspects of cigarette smoking and nicotine addition. N Engl J Med 319: 1318-1330.

Bergen AW, Korczak JF, Weissbecker KA, Goldstein AM (1999). A genome-wide search for loci contributing to smoking and alcoholism. Genet Epidemiol 17(Suppl 1): S55-60.

Bettler B, Kaupmann K, Mosbacher J, Gassmann M (2004). Molecular structure and physiological functions of GABA(B) receptors. Physiol Rev 84: 835-867.

Beuten J, Ma JZ, Payne TJ, Dupont RT, Crews KM, Somes G et al (2005a). Single- and multilocus allelic variants within the $\mathrm{GABAB}$ receptor subunit $2(\mathrm{GABAB} 2)$ gene are significantly associated with nicotine dependence. Am J Hum Genet 76: 859-864.

Beuten J, Ma JZ, Payne TJ, Dupont RT, Lou XY, Crews KM et al (2006). Association of specific haplotypes of neurotropic tyrosine kinase receptor 2 (NTRK2) gene with vulnerability to nicotine dependence in African-Americans and EuropeanAmericans. Biol Psychiatr, 17 May [Epub ahead of print].

Beuten J, Ma JZ, Payne TJ, Dupont RT, Quezada P, Huang W et al (2005b). Significant association of BDNF haplotypes in European-American male smokers but not in EuropeanAmerican female or African-American smokers. Am J Med Genet B 139: 73-80.

Bierut LJ, Rice JP, Goate A, Hinrichs AL, Saccone NL, Foroud T et al (2004). A genomic scan for habitual smoking in families of alcoholics: common and specific genetic factors in substance dependence. Am J Med Genet 124A: 19-27.

Borghesani PR, Peyrin JM, Klein R, Rubin J, Carter AR, Schwartz PM et al (2002). BDNF stimulates migration of cerebellar granule cells. Development 129: 1435-1442.
Bowery NG, Hudson AL, Price GW (1987). GABAA and GABAB receptor site distribution in the rat central nervous system. Neuroscience 20: 365-383.

Cousins MS, Roberts DC, de Wit H (2002). GABA(B) receptor agonists for the treatment of drug addiction: a review of recent findings. Drug Alcohol Depend 65: 209-220.

Epping-Jordan MP, Watkins SS, Koob GF, Markou A (1998). Dramatic decreases in brain reward function during nicotine withdrawal. Nature 393: 76-79.

Fadda P, Scherma M, Fresu A, Collu M, Fratta W (2003). Baclofen antagonizes nicotine-, cocaine-, and morphine-induced dopamine release in the nucleus accumbens of rat. Synapse 50: $1-6$.

French SJ, Humby T, Horner CH, Sofroniew MV, Rattray M (1999). Hippocampal neurotrophin and trk receptor mRNA levels are altered by local administration of nicotine, carbachol and pilocarpine. Brain Res Mol Brain Res 67: 124-136.

Ge Y, Belcher SM, Light KE (2004). Alterations of cerebellar mRNA specific for BDNF, p75NTR, and TrkB receptor isoforms occur within hours of ethanol administration to 4-day-old rat pups. Brain Res Dev Brain Res 151: 99-109.

Gelernter J, Liu X, Hesselbrock V, Page GP, Goddard A, Zhang H (2004). Results of a genomewide linkage scan: support for chromosomes 9 and 11 loci increasing risk for cigarette smoking. Am J Med Genet 128B: 94-101.

Gong W, Neill DB, Justice Jr JB (1998). GABAergic modulation of ventral pallidal dopamine release studied by in vivo microdialysis in the freely moving rat. Synapse 29: 406-412.

Hicks RR, Li C, Zhang L, Dhillon HS, Prasad MR, Seroogy KB (1999). Alterations in BDNF and trkB mRNA levels in the cerebral cortex following experimental brain trauma in rats. J Neurotrauma 16: 501-510.

Hildebrand BE, Nomikos GG, Bondjers C, Nisell M, Svensson TH (1997). Behavioral manifestations of the nicotine abstinence syndrome in the rat: peripheral versus central mechanisms. Psychopharmacology (Berlin) 129: 348-356.

Horger BA, Iyasere CA, Berhow MT, Messer CJ, Nestler EJ, Taylor JR (1999). Enhancement of locomotor activity and conditioned reward to cocaine by brain-derived neurotrophic factor. J Neurosci 19: 4110-4122.

Huang EJ, Reichardt LF (2001). Neurotrophins: roles in neuronal development and function. Annu Rev Neurosci 24: 677-736.

Huang ZJ, Kirkwood A, Pizzorusso T, Porciatti V, Morales B, Bear MF et al (1999). BDNF regulates the maturation of inhibition and the critical period of plasticity in mouse visual cortex. Cell 98: 739-755.

Hyman C, Hofer M, Barde YA, Juhasz M, Yancopoulos GD, Squinto SP et al (1991). BDNF is a neurotrophic factor for dopaminergic neurons of the substantia nigra. Nature 350: 230-232.

Kaplan DR, Stephens RM (1994). Neurotrophin signal transduction by the Trk receptor. J Neurobiol 25: 1404-1417.

Kenny PJ, File SE, Rattray M (2000). Acute nicotine decreases, and chronic nicotine increases the expression of brain-derived neurotrophic factor mRNA in rat hippocampus. Brain Res $\mathrm{Mol}$ Brain Res 85: 234-238.

Kubo T, Nonomura T, Enokido Y, Hatanaka H (1995). Brainderived neurotrophic factor (BDNF) can prevent apoptosis of rat cerebellar granule neurons in culture. Brain Res Dev Brain Res 85: $249-258$.

Kubota H, Katsurabayashi S, Moorhouse AJ, Murakami N, Koga H, Akaike N (2003). GABAB receptor transduction mechanisms, and cross-talk between protein kinases $A$ and $C$, in GABAergic terminals synapsing onto neurons of the rat nucleus basalis of Meynert. J Physiol 551: 263-276.

Le Foll B, Diaz J, Sokoloff P (2005). A single cocaine exposure increases BDNF and D3 receptor expression: implications for drug-conditioning. Neuroreport 16: 175-178. 
Li MD, Cheng R, Ma JZ, Swan GE (2003a). A meta-analysis of estimated genetic and environmental effects on smoking behavior in male and female adult twins. Addiction 98: 23-31.

Li MD, Ma JZ, Cheng R, Dupont RT, Williams NJ, Crews KM et al (2003b). A genome-wide scan to identify loci for smoking rate in the Framingham Heart Study population. BMC Genet 4(Suppl 1): S103.

Li SP, Park MS, Kim JH, Kim MO (2004). Chronic nicotine and smoke treatment modulate dopaminergic activities in ventral tegmental area and nucleus accumbens and the gammaaminobutyric acid type $B$ receptor expression of the rat prefrontal cortex. J Neurosci Res 78: 868-879.

Lin X, Cui H, Bulleit RF (1998). BDNF accelerates gene expression in cultured cerebellar granule neurons. Brain Res Dev Brain Res 105: 277-286.

Ma JZ, Zhang D, Dupont RT, Dockter ME, Elston RC, Li MD (2003). Mapping susceptibility loci for alcohol consumption using number of grams of alcohol consumed per day as a phenotype measure. BMC Genetics 4(Suppl I): S104.

Maggio R, Riva M, Vaglini F, Fornai F, Molteni R, Armogida M et al (1998). Nicotine prevents experimental parkinsonism in rodents and induces striatal increase of neurotrophic factors. J Neurochem 71: 2439-2446.

Malin DH, Lake JR, Newlin-Maultsby P, Roberts LK, Lanier JG, Carter VA et al (1992). Rodent model of nicotine abstinence syndrome. Pharmacol Biochem Behav 43: 779-784.

Martin SC, Russek SJ, Farb DH (1999). Molecular identification of the human GABABR2: cell surface expression and coupling to adenylyl cyclase in the absence of GABABR1. Mol Cell Neurosci 13: $180-191$.

Martin SC, Russek SJ, Farb DH (2001). Human GABA(B)R genomic structure: evidence for splice variants in GABA(B)R1 but not GABA(B)R2. Gene 278: 63-79.

Meredith GE, Callen S, Scheuer DA (2002). Brain-derived neurotrophic factor expression is increased in the rat amygdala, piriform cortex and hypothalamus following repeated amphetamine administration. Brain Res 949: 218-227.

Mizoguchi Y, Ishibashi H, Nabekura J (2003a). The action of BDNF on $\mathrm{GABA}(\mathrm{A})$ currents changes from potentiating to suppressing during maturation of rat hippocampal CA1 pyramidal neurons. J Physiol 548: 703-709.

Mizoguchi Y, Kanematsu T, Hirata M, Nabekura J (2003b). A rapid increase in the total number of cell surface functional GABAA receptors induced by brain-derived neurotrophic factor in rat visual cortex. J Biol Chem 278: 44097-44102.

Murrin LC, Ferrer JR, Zeng WY, Haley NJ (1987). Nicotine administration to rats: methodological considerations. Life Sci 40: 1699-1708.

Nakagawara A, Liu XG, Ikegaki N, White PS, Yamashiro DJ, Nycum LM et al (1995). Cloning and chromosomal localization of the human TRK-B tyrosine kinase receptor gene (NTRK2). Genomics 25: 538-546.

Narita M, Aoki K, Takagi M, Yajima Y, Suzuki T (2003). Implication of brain-derived neurotrophic factor in the release of dopamine and dopamine-related behaviors induced by methamphetamine. Neuroscience 119: 767-775.

Paterson NE, Bruijnzeel AW, Kenny PJ, Wright CD, Froestl W, Markou A (2005). Prolonged nicotine exposure does not alter $\mathrm{GABA}(\mathrm{B})$ receptor-mediated regulation of brain reward function. Neuropharmacology 49: 953-962.
Paxinos G, Watson C (1986). The Rat Brain in Stereotaxic Coordinates, xxvi edn. Academic Press: Sydney.

Pontieri FE, Tanda G, Orzi F, Di Chiara G (1996). Effects of nicotine on the nucleus accumbens and similarity to those of addictive drugs. Nature 382: 255-257.

Rieff HI, Raetzman LT, Sapp DW, Yeh HH, Siegel RE, Corfas G (1999). Neuregulin induces GABA(A) receptor subunit expression and neurite outgrowth in cerebellar granule cells. J Neurosci 19: 10757-10766.

Rose JE, Corrigall WA (1997). Nicotine self-administration in animals and humans: similarities and differences. Psychopharmacology (Berlin) 130: 28-40.

Spina MB, Squinto SP, Miller J, Lindsay RM, Hyman C (1992). Brain-derived neurotrophic factor protects dopamine neurons against 6-hydroxydopamine and $\mathrm{N}$-methyl-4-phenylpyridinium ion toxicity: involvement of the glutathione system. J Neurochem 59: $99-106$

Sullivan PF, Kendler KS (1999). The genetic epidemiology of smoking. Nicotine Tob Res 1(Suppl 2): S51-S57; discussion S69-s70.

Tapia-Arancibia L, Rage F, Givalois L, Arancibia S (2004). Physiology of BDNF: focus on hypothalamic function. Front Neuroendocrinol 25: 77-107.

Tapia-Arancibia L, Rage F, Givalois L, Dingeon P, Arancibia S, Beauge F (2001). Effects of alcohol on brain-derived neurotrophic factor mRNA expression in discrete regions of the rat hippocampus and hypothalamus. J Neurosci Res 63: 200-208.

Valent A, Danglot G, Bernheim A (1997). Mapping of the tyrosine kinase receptors trkA (NTRK1), trkB (NTRK2) and trkC(NTRK3) to human chromosomes 1q22, 9q22 and $15 \mathrm{q} 25$ by fluorescence in situ hybridization. Eur J Hum Genet 5: 102-104.

Wang D, Ma JZ, Li MD (2005). Mapping and verification of susceptibility loci for smoking quantity using permutation linkage analysis. Pharmacogenom J 5: 166-172.

Watkins SS, Stinus L, Koob GF, Markou A (2000). Reward and somatic changes during precipitated nicotine withdrawal in rats: centrally and peripherally mediated effects. J Pharmacol Exp Ther 292: 1053-1064.

Winer J, Jung CK, Shackel I, Williams PM (1999). Development and validation of real-time quantitative reverse transcriptasepolymerase chain reaction for monitoring gene expression in cardiac myocytes in vitro. Anal Biochem 270: 41-49.

Yeom M, Shim I, Lee HJ, Hahm DH (2005). Proteomic analysis of nicotine-associated protein expression in the striatum of repeated nicotine-treated rats. Biochem Biophys Res Commun 326: 321-328.

Zaidi SI, Jafri A, Doggett T, Haxhiu MA (2005). Airway-related vagal preganglionic neurons express brain-derived neurotrophic factor and TrkB receptors: implications for neuronal plasticity. Brain Res 1044: 133-143.

Zhang L, Dhillon HS, Barron S, Hicks RR, Prasad RM, Seroogy KB (2000). Effects of chronic ethanol administration on expression of BDNF and trkB mRNAs in rat hippocampus after experimental brain injury. Brain Res Mol Brain Res 79: 174-179.

Zirrgiebel U, Ohga Y, Carter B, Berninger B, Inagaki N, Thoenen H et al (1995). Characterization of TrkB receptor-mediated signaling pathways in rat cerebellar granule neurons: involvement of protein kinase $C$ in neuronal survival. J Neurochem 65: $2241-2250$. 